\title{
Two deep-living rhodaliids (Cnidaria, Siphonophora) from the Mid-Atlantic Ridge
}

\author{
Mapstone Gillian M. ${ }^{1,}$, Corbari Laure ${ }^{2}$, Menot Lenaick ${ }^{3}$
}

${ }^{1}$ Nat Hist Museum, Dept Life Sci, Cromwell Rd, London SW7 5BD, England.

2 Museum Natl Hist Nat, Inst Systemat Evolut \& Biodiversite, UMR 7205, Paris, France.

${ }^{3}$ Ctr Bretagne, IFREMER, REM EEP, Lab Environm Profond, Plouzane, France.

*Corresponding author : Gillian M. Mapstone, email address : g.mapstone@nhm.ac.uk

\begin{abstract}
:
Rhodaliids are a semi-benthic family of 14 physonect siphonophore species found in all oceans, except the Mediterranean and Arctic. They inhabit species-specific depth ranges in isolated locations and records are mostly sparse. Here, the first ever observations of rhodaliids from the Mid-Atlantic Ridge are given, from three images of two putative species. They come from depths of 3482 and 3667-3670 metres, on the Mid-Atlantic Ridge (MAR) at $23^{\circ} \mathrm{N}$ and $26^{\circ} \mathrm{N}$, near two hydrothermal vents. Rhodaliids are very delicate animals and extremely hard to sample, particularly from such great depths, and the only comparable deep-living species so far described is the Galapagos Dandelion (Thermopalia taraxaca) from 2480-2938 metres on the Galapagos Rift and East Pacific Rise. This species inhabits the outer zone of certain hydrothermal vents where there is no hydrogen sulphide in the water, but connectivity with the MAR species is unlikely, since the latter inhabit a different ocean basin. Two, or possibly three, rhodaliid species have so far been collected in the North Atlantic, and all occurred near continental margins. These new observations are therefore important, and the images included here will hopefully alert future expeditions to hunt for, and perhaps even collect, more specimens. Rhodaliids are mostly observed individually adhering to a variety of substrata with their long tentacles, but very occasionally abundances of from 1 to 11 individuals $m-2$ have been noted. Rhodaliids feed on copepods, other small pelagic crustaceans and fish larvae, and can thus represent important members of deep-sea ecosystems. This paper provides a distribution map of all species with an accompanying table showing coordinates, depths and number of specimens collected, and a second table of comparative diagnostic rhodaliid characters, which is used to suggest possible identities for the two putative new MAR species.
\end{abstract}

Keywords : Deep-sea, Mid-Atlantic Ridge, rhodaliid, siphonophore 


\section{Introduction}

Rhodaliids are the only benthic family of the little known hydrozoan group Siphonophora (Phylum Cnidaria), and are classified in the traditional sub-group Physonectae (Pugh 1983). A rhodaliid comprises a small spherical corm with protruding zooids supported by a gas-filled float (pneumatophore), which suspends the animal just above the bottom. The widest part of the corm is typically the siphosome, of two or more whorls of iterative units (cormidia), above which the corm narrows into the nectosome. Here, flimsy transparent swimming bells (nectophores) are arranged in a ring. Tentacles emerge from feeding zooids on the cormidia and attach the colony to the substrate, as shown in several published figures of rhodaliids (Hissmann et al 1995 fig. 7; Mapstone \& Ljubenkov 2013 fig. 1c). Each cormidium always includes one or more feeding zooids (gastrozooids), typically also a number of digestive or excretory zooids (gonopalpons) and, when sexually mature, many reproductive zooids (gonophores). Zooids are all carried on one or more branched tree-like structures comprising either a single stem or a stalk bearing several stems. Rhodaliids uniquely possess two types of gastrozooids: type II gastrozooids each with an extremely long tentacle bearing numerous attached stinging batteries (tentilla) for prey capture, plus larger type I gastrozooids, which collect prey from the tentilla of the type II tentacles and digest it. This feeding activity is well described in live shallow-living rhodaliids from Indonesia and South Africa by Hissmann (2005, p.241).

\section{Materials and methods}

Photographic images (screen shots) and video footage of two rhodaliid morpho-types were taken by the ROV Victor 6000 (IFREMER) at two hydrothermal vent sites on the Mid-Atlantic Ridge: Snake Pit and TAG, during the BICOSE cruise, in JanuaryFebruary 2014. Video footage was combined into a video file, available in Supplemental material, Video clip SI. These images are compared and contrasted below with descriptions and published images of all known rhodaliid species from elsewhere. Preserved specimens of two species previously collected in the North Atlantic were also examined: Angelopsis euryale Pugh, 1983 (holotype, NHM Reg. No. 1982.2.2.1) and Stephalia corona Haeckel, 1888(NHM Reg. No. 1973.5.9.5), from the collections of the Natural History Museum, London. 


\section{Results}

\section{Distribution}

Although the life cycle of rhodaliids is unknown, specimens of all 14 species currently considered valid occur in every ocean except the Mediterranean (Figure 1). Distribution is limited both geographically and vertically and specimens have been collected from continental shelves and margins, island shelves, a seamount, and from deeper water at one (and now three) hydrothermal vent fields. The two tentative new morpho-species are the first rhodaliids to be recorded from the Mid-Atlantic Ridge region in the North Atlantic. They represent the deepest records so far documented for any rhodaliid siphonophore (Table I). Eight of the named rhodaliid species are restricted to depth horizons above $1000 \mathrm{~m}$, five to below $1000 \mathrm{~m}$ and one species occurs above and just below 1000m.

\section{INSERT TABLE I}

Rhodaliids are also limited to particular ocean basins, presumably because they are benthic and their siphonula larvae can only live in the plankton (where they are transported by ocean currents) for a few weeks before descending to become new adult colonies, as deduced from the development time estimated for the agalmatid physonect Nanomia bijuga (Delle Chiaje, 1844) by Carré (1969). Siphonophores are extremely delicate organisms, and the few rhodaliids captured alive have only ever survived for one or two days in a tank before disintegrating (Hissmann 2005). Thus, rhodaliids are unlikely to ever be reared in the laboratory.

The three species of rhodaliids previously collected in the North Atlantic include Stephalia corona from off NW Scotland and the West African coast, and two species of the genus Angelopsis, including A. globosa Fewkes, 1886 from the NW Atlantic and also A. euryale from off the West African coast. The locations of these, and all other specimens collected worldwide, including the two tentative new morphospecies, are shown in a world map (Figure 1) and listed in Table I. Angelopsis globosa is known only from two denuded specimens collected by the US Fisheries Commission Steamer Albatross from deep water off the US coast with a beam trawl, 
which had lost all their nectophores and most cormidia during collection. They were described by Fewkes (1886, 1889), but have since been lost (Pugh 1983). The species was reassessed by Pugh (1983) based on the figures of Fewkes and retained as valid pending the collection of further better quality material from the same area. In his 1983 paper, Pugh also introduces a second species A. euryale from the eastern N Atlantic, from three extant, but also denuded specimens (Table I). Based on geographical distribution alone, it seems possible that the two new morpho-species might be $S$. corona and A. euryale, since they occur at similar latitudes (Figure 1, Table I). But both are from water slightly deeper than A. euryale and considerably deeper than $S$. corona (Table I). Their morphology also does not necessarily agree with that known for S. corona and A. euryale (see below).

\section{INSERT FIGURE 1}

\section{Morphology}

Morphology is important for successful rhodaliid species identification, and descriptions of the 14 species so far published can be found in Pugh (1983), Hissmann et al (1995), Hissmann (2005) and Mapstone and Ljubenkov (2013). Enlarged and slightly enhanced images of the tentative new MAR species are given in Figures 2A and $2 \mathrm{C}$, with comparative diagrams in Figures $2 \mathrm{~B}$ and 2D. A list of diagnostic characters useful for identifying rhodaliids is given in Table II (with those for two similar genera combined). These characters include colony colour, texture of the float (pneumatophore) and gas gland (aurophore), number of nectophores below the float, type of corm (thick or thin walled), arrangement and type of cormidia on the corm (typically in 2 or more whorls) including types of zooids present and the likely ratio and positions of type I and type II gastrozooids. The amount of information available varies for each genus and species, and is much greater for species observed and collected more recently with ROVs than for species collected earlier with trawls (Angelopsis species, Rhodalia miranda Haeckel, 1888). In the latter most or all of the zooids have been lost and no in situ observations made. 


\section{INSERT TABLE II}

\section{Mid-Atlantic Species A.}

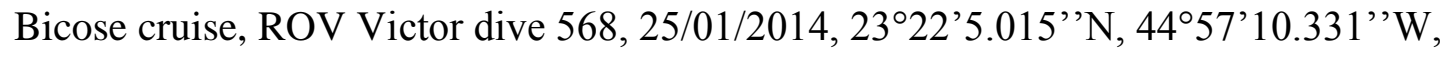
$3482 \mathrm{~m}$, at $16 \mathrm{~m}$ of a diffuse vent site of the Snake Pit vent field (Figure $2 \mathrm{~A}$ and B; MAR video SI). This specimen has many tentacles deployed for attachment, particularly on the lower left side, suggesting the colony experiences a strong prevailing current either periodically or continuously from a lower left direction (in Figure 2A). A clear pneumatophore (float) is not apparent, although it is likely to be the translucent white structure displaced to the upper right in Figure 2A, from which may emerge part of the aurophore (top right). Both structures are labelled in Figure 2B, but unfortunately their surface textures cannot be fully assessed from Figure 2A. The soft and probably almost invisible nectophores may occupy a space to the left and below the pneumatophore, perhaps represented by some faintly tinged yellow structures, possibly folded over (as in some other rhodaliid species, see Hissmann 2005), and overlying the orange cormidial zooids in this region (Figure 2B). The most obvious structures on the corm are the orange siphosomal zooids, which are numerous, have white tips, and appear to extend out from the internal siphosomal corm at all angles. They are probably either all type II gastrozooids, or a mixture of type II gastrozooids and gonopalpons, since no particularly large type I gastrozooids are apparent in Figure 2A. Perhaps these latter zooids may be restricted to the base of the corm as in many other rhodaliids in Table II, and thus hidden from view in Figure 2A. Many long, thin, pale grey tentacles emerge from the type II gastrozooids in Figure 2A, a selection of which are shown in Figure 2B.

\section{INSERT FIGURE 2}

\section{Mid-Atlantic Species B.}

Bicose cruise, ROV Victor dive 575, 04/02/2014, 268'14.284', 4449'26.857', $3670 \mathrm{~m}$ and $26^{\circ} 8^{\prime} 13.829^{\prime}, 4^{\circ} 49^{\prime} 27.411^{\prime},, 3667 \mathrm{~m}$ at 135 to $150 \mathrm{~m}$ of the TAG vent field (Figure 2C and D; MAR video SI). This specimen, and another larger one of poorer resolution photographed nearby, show that Species B is much paler in colour than Species A and has a clear central pneumatophore (with internal reflective gas bubble) surrounded by a translucent white ring (corona) of many likely nectophores, 
perhaps also folded over since no ostia (nectophore openings) can be discerned. This corona partially covers two structures, one pink and one white (Figure 2D), one of which may represent part of the aurophore. A pale pink translucent region around the nectophores could represent bracts, which are prominent in some other rhodaliid species, and, emerging from the corm in this region are nine dense whitish rounded structures which could be type I gastrozooids (Figure 2C) (see also discussion for possible alternative identity). One, or more, longer orange zooids also project from the corm, which could be either type II gastrozooids or gonopalpons (Figure 2D). Probably there are more such orange zooids hidden from view in Figure 2C. Few tentacles can be discerned in this specimen, suggesting perhaps that it has fewer type II gastrozooids than Species A, or alternatively, that the current is much weaker at this location. The larger specimen omitted from Figure $2 \mathrm{C}$ has c.13 large white tentative type I gastrozooids extending out from around the corm, and also at least one thinner elongate dark orange zooid (see MAR video clip SI).

MAR video footage suggests disturbance by the ROV, resulting in detachment of all but one tentacle in both specimens, allowing each to drift somewhat to the left. Siphonophore tentacles are capable of extension to prodigious lengths when relaxed and feeding (Mackie \& Boag 1963) and extremely elongated tentacles have been observed in particular in rhodaliids by Hissmann (2005), albeit in calm conditions. Reattachment of detached tentacles can be rapid (Hissmann 2005), and this strategy may prevent disturbed colonies from being carried away completely by bottom currents, when they are present.

\section{Discussion}

Species A:

Little is known of the external morphology of Angelopsis euryale, the rhodaliid found at a similar latitude from a similar depth horizon in the North Atlantic (Figure 1, Table I). No live image of A. euryale is available, and preserved specimens lack any cormidial units on the siphosome (Table II). However, scars from type I gastrozooids are evident on the base of the corm of A. euryale, as described and figured by Pugh (1983) and noted by GMM in the NHM holotype (see above). Also images in the literature show orange-coloured siphosomal zooids in many rhodaliids and thus 
Species A may well represent A. euryale. Alternatively, because the ratio of tentacles to orange white-tipped siphosomal zooids could be circa 1:1, this species may perhaps lack gonopalpons and instead represent a new and second species in the genus Thermopalia (Table II). Certainly all the siphosomal zooids look alike, apart from slight variation in thickness (Figure 2A), whereas in live images of other rhodaliids with orange zooids, gonopalpons appear thinner and more numerous than, type II gastrozooids (see Pugh 1983 pl. 6 fig. 8, of Stephalia corona). Should specimens of Species A be collected in the future, then more conclusive identification to species level will be possible.

\section{Species B:}

The striking feature of this species is its very pale pink colour and presence around the corm of a number of large, white zooid-like structures quite unlike the numerous orange zooids in Species A, although a few of the latter zooids are visible also in Figures 2C and D. The white zooids resemble large pale type I gastrozooids on the siphosome of the shallow water Indonesian rhodaliid Tridensa rotunda Hissmann, 2005, as photographed in a tank after capture (Hissmann 2005, fig. 1b). This latter specimen also has a number of large bracts just below the nectosome. No other image of a live rhodaliid with such large gastrozooids has yet been published, and never from the depths inhabited by Species B.

Other possible affinities of Species B might be Angelopsis euryale, but this species has type I gastrozooids probably restricted to the base of the corm, as noted above. Perhaps the white zooids are not type I gastrozooids, but eggs sacs of a parasitic pycnogonid known to infest some rhodaliid specimens in Japanese waters (Dhugal Lindsay, pers. comm. 2015). In this case, Species B specimens might possibly represent parasitized individuals of Species A. However, these white structures are quite regularly arranged in Species B, and each appears to have a proboscis, albeit swollen, distinct from the column (Figure 2D). The identity of these zooids can only be confirmed once fresh specimens of Species B are collected. Meanwhile, Species B is tentatively assigned to a new species in the genus Tridensa, currently known only from shallow locations around Indonesia (Table 1). 
Rhodalia miranda and Arancialia captonia Hissmann, 2005 from the South Atlantic (Table 1, Figure 1), inhabit a different ocean basin to Species A and B, and it is unlikely that their larvae would survive the long journey from $37^{\circ} \mathrm{S}$ to $23^{\circ} \mathrm{N}$ since deep seafloor transform faults and associated currents in the equatorial region have been shown to form a barrier to larval dispersal in other mid-Atlantic vent species (van Heijden et al. 2012, Ramirez-Llodra et al. 2007).

It is interesting to speculate what prey the tentilla of Species A and B might be capturing in the Snake Pit and TAG vent fields. Rhodaliid tentilla are small, but clearly visible when extended for feeding in A. captonia (off Cape Town, Hissmann 2005 fig. 1h). Arancialia captonia is the only rhodaliid species so far in which feeding has been observed; it appears to be a generalist feeder, capturing prey in the size range 1 - $10 \mathrm{~mm}$ length, from small rounded amphipods to larger fish larvae (Hissmann 2005). Potential prey within this range available to Species A and B could include larvae of molluscs, various copepod and amphipod species, juvenile stages of the decapod shrimp Rimicaris exoculata Williams \& Rona, 1986 and others, and possibly even zoea and megalopa larvae of the several crab species collected at Mid-Atlantic Ridge vents (Desbruyères et al. 2006).

\section{Acknowledgements}

Thanks to the ROV (Remotely Operated Vehicle) team at IFREMER, Brest, France, and to Barry Mapstone for drafting the figures. Special thanks to the crew, scientists and chief scientist (Marie-Anne Cambon-Bonavita) involved in the BICOSE cruise. The research leading to these results has received funding from the European Union Seventh Framework Programme (FP7/2007-2013) under the MIDAS project, grant agreement $n^{\circ} 603418$.

\section{References:}

Araujo EM. 2012. Sistemática y distribución de los sifonóforos (Cnidaria/Hydrozoa) del Océano Atlántico Sudoccidental. Doctoral Thesis. Universidad Nacional de Mar del Plata (Argentina): Facultad de Ciencias Exactas y Naturales.197 pages. (in Spanish) 
Ballard RD, Grasslé JF. 1979. Return to oases of the deep. National Geographic Magazine 156:689-703.

Burton EJ, Lundsten L. 2008. Davidson Seamount Taxonomic Guide. Marine Sanctuaries Conservation Series ONMS-08-08. Silver Springs: US Department of Commerce, National Oceanic and Atmospheric Administration, Office of National Marine Sanctuaries, Silver Spring, MD: 145 pages.

Carré, D. 1969. Étude histologique du développement de Nanomia bijuga (Chiaje, 1841), siphonophore physonecte, Agalmidae. Cahiers de Biologie Marine 10: 325-41. (in French)

Desbruyères DI, Segonzac M, Bright M. 2006. Handbook of Deep-Sea Hydrothermal Vent Fauna. Linz, Biologizentrum /Oberösterreichisches Landesmuseum. 544 pages.

Dunn CW, Pugh PR, Haddock SHD. 2005. Molecular phylogenetics of the Siphonophora (Cnidaria), with implications for the evolution of functional specialisation. Systematic Biology 54:916-35.

Fewkes JW. 1886. Medusae collected by the USFC Steamer "Albatross", in the region of the Gulf Stream, in 1883-84. Report of Commissioner of Fish and Fisheries Washington 26:927-80.

Fewkes JW. 1889. On Angelopsis, and its relationship to certain Siphonophora taken by the "Challenger." Annals and Magazine of Natural History, 6th series $4: 146-55$.

Gutt J, Starmans A. 1998. Structure and biodiversity of megabenthos in the Weddell and Lazarev Seas (Antarctica): ecological role of physical parameters and biological interactions. Polar Biology 20:229-47.

Hissmann K 2005. In situ observations on benthic siphonophores (Physonectae: Rhodaliidae) and descriptions of three new species from Indonesia and South Africa. Systematics and Biodiversity 2:223-49.

Hissmann K, Schauer J, Pugh PR. 1995. Archangelopsis jagoa, a new species of benthic siphonophore (Physonectae, Rhodaliidae) collected by submersible in the Red Sea. Oceanologica Acta 18:671-80.

Kitamura M, Miyake H, Lindsay DJ. 2008. Cnidaria. In: Fujikura K, Okutani T, Maruyama T, editors. Deep-Sea life - Biological Observations using Research Submersibles. Kanagawa: Tokai University Press, p 295-320. 
Mackie GO, Boag DA. 1963. Fishing, feeding and digestion in siphonophores.

Pubblicazioni Della Stazione Zoologica di Napoli. 33:178-96.

Mapstone GM, Ljubenkov JC. 2013. New observations on Dromalia alexandri

Bigelow, 1911, a rhodaliid physonect siphonophore from southern Californian waters. Marine Ecology. 34:96-112.

Mapstone GM. 2014. Global Diversity and Review of Siphonophorae (Cnidaria: Hydrozoa). PLOS ONE 9(2):e87737. 37 pages.

Miyake H, Lindsay DJ. 2013. Encyclopedia of Jellyfish. Tokyo, Japan: SeibundoShinkosha. 128 pages. (in Japanese)

Moser F. 1924. Siphonophoren. In: Kükenthal W, Krumbach T, editors. Handbuch der Zoologie. Berlin: Walter de Gruyter, p 485-521. (in German)

Pugh PR. 1983. Benthic siphonophores: a review of the family Rhodaliidae (Siphonophora, Physonectae). Philosophical Transactions of the Royal Society B: Biological Science 301:165-300.

Ramirez-Llodra E, Shank TM, German CR. 2007. Biodiversity and biogeography of hydrothermal vent species. Oceanography 20:30-41.

van der Heijden K, Petersen JM, Dubilier N, Borowski C. 2012. Genetic Connectivity between North and South Mid-Atlantic Ridge Chemosynthetic Bivalves and Their Symbionts. PLOS ONE 7(7): e39994. 14 pages. 
Table I. Coordinates for all rhodaliid species

\begin{tabular}{|c|c|c|c|c|c|}
\hline & Species & Ocean & Lat & Long & Depth \& reference ${ }^{\text {(source) }}$ \\
\hline 1 & $\begin{array}{l}\text { Mid-Atlantic } \\
\text { Species } 1 \text { (orange) }\end{array}$ & $\begin{array}{l}\text { Atlantic } \\
\text { (Snake Pit) }\end{array}$ & $23^{\circ} 22.08^{\prime} \mathrm{N}$ & $44^{\circ} 57.2^{\prime} \mathrm{W}$ & $3494 m$ (image only) \\
\hline 2 & $\begin{array}{l}\text { Mid-Atlantic } \\
\text { Species } 2 \text { (white) }\end{array}$ & $\begin{array}{l}\text { Atlantic } \\
\text { (TAG) }\end{array}$ & $26^{\circ} 08.24^{\prime} \mathrm{N}$ & $44^{\circ} 49.45^{\prime} \mathrm{W}$ & $\begin{array}{l}3647 \text { and } 3644 \mathrm{~m} \mathrm{(2} \\
\text { images only) }\end{array}$ \\
\hline 3 & $\begin{array}{l}\text { Angelopsis } \\
\text { euryale Pugh, } \\
1983\end{array}$ & Atlantic & $20^{\circ} 50.1^{\prime} \mathrm{N}$ & $18^{\circ} 55.5^{\prime} \mathrm{W}$ & $\begin{array}{l}\text { 3109-3089m (Type, of } 3 \\
\text { specimens) }\end{array}$ \\
\hline 4 & $\begin{array}{l}\text { Angelopsis } \\
\text { globosa Fewkes, } \\
1886\end{array}$ & Atlantic & $37^{\circ} 50^{\prime} \mathrm{N}$ & $73^{\circ} 03^{\prime} 50^{\prime \prime} \mathrm{W}$ & $\begin{array}{l}\text { 2553m (Type, of } 2 \\
\text { specimens) }\end{array}$ \\
\hline \multirow[t]{2}{*}{5} & $\begin{array}{l}\text { Arancialia } \\
\text { captonia } \\
\text { Hissmann, } 2005\end{array}$ & $\begin{array}{l}\text { Table Bay, } S \\
\text { Africa }\end{array}$ & $33^{\circ} 55.37^{\prime} \mathrm{S}$ & $18^{\circ} 10.34^{\prime} \mathrm{E}$ & $\begin{array}{l}123-125 \mathrm{~m} \text { (Type, of } 3 \\
\text { specimens) }\end{array}$ \\
\hline & & Cape Point & $34^{\circ} 31.30^{\prime} \mathrm{S}$ & $17^{\circ} 58.96^{\prime} \mathrm{E}$ & $359 \mathrm{~m}(1 \text { specimen })^{2}$ \\
\hline \multirow[t]{2}{*}{6} & $\begin{array}{l}\text { Archangelopsis } \\
\text { jagoa Hissmann, } \\
\text { Schauer \& Pugh, } \\
1995\end{array}$ & $\begin{array}{l}\text { Gulf of } \\
\text { Aqaba }\end{array}$ & $29^{\circ} 31^{\prime} \mathrm{N}$ & $34^{\circ} 56^{\prime} \mathrm{E}$ & $\begin{array}{l}\text { 370m (Type, of } 1 \\
\text { specimen), } 272,252 \mathrm{~m}(2 \\
\text { paratypes) }\end{array}$ \\
\hline & & $\begin{array}{l}\text { Comores Is, } \\
\text { Indian Ocean }\end{array}$ & $11^{\circ} 51.6^{\prime} \mathrm{S}$ & $43^{\circ} 21.2^{\prime} \mathrm{E}$ & $\begin{array}{l}256,178,196 \mathrm{~m} \mathrm{(3} \\
\text { specimens })^{2}\end{array}$ \\
\hline \multirow[t]{2}{*}{7} & $\begin{array}{l}\text { Archangelopsis } \\
\text { typical Lens \& } \\
\text { van Riemsdijk, } \\
1908\end{array}$ & Indo-Pacific & $07^{\circ} 02.6^{\prime} \mathrm{S}$ & $115^{\circ} 23.6^{\prime} \mathrm{E}$ & $\begin{array}{l}\text { 100m (Type, of } 2 \\
\text { specimens) }\end{array}$ \\
\hline & & $\begin{array}{l}\text { East China } \\
\text { Sea }\end{array}$ & $32^{\circ} 31^{\prime} 10^{\prime \prime} \mathrm{N}$ & $128^{\circ} 33^{\prime} 20^{\prime \prime} \mathrm{E}$ & $254 \mathrm{~m}(1 \text { specimen })^{1}$ \\
\hline \multirow[t]{3}{*}{8} & $\begin{array}{l}\text { Dromalia } \\
\text { alexandri } \\
\text { Bigelow, } 1911 \\
\end{array}$ & $\begin{array}{l}\text { Southern } \\
\text { California } \\
\text { Bight }\end{array}$ & $32^{\circ} 43^{\prime} \mathrm{N}$ & $117^{\circ} 51^{\prime} \mathrm{W}$ & $\begin{array}{l}\text { 572?m (Type, of } 15 \\
\text { specimens) }\end{array}$ \\
\hline & & $\begin{array}{l}\text { Monterey } \\
\text { Canyon }\end{array}$ & c. $37^{\circ} \mathrm{N}$ & c. $132^{\circ} \mathrm{W}$ & $\begin{array}{l}150-750 m \text { total }(218+20 \\
\text { specimens }) \text {; northernmost } \\
\text { record }{ }^{5}\end{array}$ \\
\hline & & $\begin{array}{l}\text { Off Baha } \\
\text { California } \\
\text { Sur }\end{array}$ & $27^{\circ} 28.3^{\prime} \mathrm{N}$ & $114^{\circ} 51.0^{\prime} \mathrm{W}$ & $\begin{array}{l}110 \mathrm{~m} \text { (5 specimens); } \\
\text { southernmost record }\end{array}$ \\
\hline \multirow[t]{7}{*}{9} & $\begin{array}{l}\text { Rhodalia miranda } \\
\text { Haeckel, } 1888\end{array}$ & S Atlantic & $37^{\circ} 17^{\prime} \mathrm{S}$ & $53^{\circ} 52^{\prime} \mathrm{W}$ & $\begin{array}{l}\text { 1098m (Type, of } 4 \\
\text { specimens) }\end{array}$ \\
\hline & & & $51^{\circ} 18^{\prime} \mathrm{S}$ & $56^{\circ} 31.3^{\prime} \mathrm{W}$ & $470-455 \mathrm{~m}$ (6 specimens) \\
\hline & & & $49^{\circ} 00.8^{\prime} \mathrm{S}$ & $59^{\circ} 07.6^{\prime} \mathrm{W}$ & $525-515 \mathrm{~m}$ (3 specimens) \\
\hline & & & $46^{\circ} 37^{\prime} \mathrm{S}$ & $59^{\circ} 23^{\prime} \mathrm{W}$ & $1070 \mathrm{~m}(2 \text { specimens })^{1}$ \\
\hline & & & $53^{\circ} 05-08^{\prime} \mathrm{S}$ & $59^{\circ} 31-34^{\prime} \mathrm{W}$ & $512-586 m$ (1 specimen) ${ }^{1}$ \\
\hline & & & $46-47.5^{\circ} \mathrm{S}$ & c. $60^{\circ} \mathrm{W}$ & $0 ?(47 \text { specimens })^{9}$ \\
\hline & & Weddell Sea & c. $75^{\circ} \mathrm{S}$ & $30^{\circ} \mathrm{W}$ & $\begin{array}{l}\text { Records of unknown } \\
\text { number of images } 4,9\end{array}$ \\
\hline 10 & $\begin{array}{l}\text { Steleophysema } \\
\text { aurophora } \text { Moser, } \\
1924\end{array}$ & $\begin{array}{l}\text { Sagami Bay } \\
\text { \& Sagami } \\
\text { Knoll, Japan }\end{array}$ & $\begin{array}{l}35^{\circ} 10^{\prime} \mathrm{N} \\
35^{\circ} 08.5^{\prime} \mathrm{N}\end{array}$ & $\begin{array}{l}139^{\circ} 30^{\prime} \mathrm{E} \\
139^{\circ} 22.5^{\prime} \mathrm{E}\end{array}$ & $\begin{array}{l}\text { 450m, 462m (1 } \\
\text { specimen, } 1 \text { image }{ }^{1,10,12} \\
\text { 400-500m (1 image })^{11}\end{array}$ \\
\hline 11 & $\begin{array}{l}\text { Stephalia } \\
\text { bathyphysa } \\
\text { (Haeckel, 1888) }\end{array}$ & SE Pacific & $38^{\circ} 50^{\prime} \mathrm{S}$ & $169^{\circ} 20^{\prime} \mathrm{E}$ & $\begin{array}{l}503 \mathrm{~m} \text { (Type, of } 2 \\
\text { specimens) }\end{array}$ \\
\hline \multirow[t]{4}{*}{12} & $\begin{array}{l}\text { Stephalia corona } \\
\text { Haeckel, } 1888\end{array}$ & NE Atlantic & $60^{\circ} 18^{\prime} \mathrm{N}$ & $6^{\circ} 15^{\prime} \mathrm{W}$ & $\begin{array}{l}\text { 1170m (Type, of } 2 \\
\text { specimens) }\end{array}$ \\
\hline & & & $59^{\circ} 40^{\prime} \mathrm{N}$ & $7^{\circ} 21^{\prime} \mathrm{W}$ & $\begin{array}{l}\text { 945m (Type, of } 2 \\
\text { specimens) }\end{array}$ \\
\hline & & & $59^{\circ} 35^{\prime} \mathrm{N}$ & $7^{\circ} 00^{\prime} \mathrm{W}$ & $1140 \mathrm{~m}(1 \text { specimen })^{1}$ \\
\hline & & & $23^{\circ} 53.0^{\prime} \mathrm{N}$ & $17^{\circ} 26.9^{\prime} \mathrm{W}$ & $1500 \mathrm{~m}(2$ specimens $){ }^{1}$ \\
\hline
\end{tabular}




\begin{tabular}{|c|c|c|c|c|c|}
\hline & & & $25^{\circ} 51.7^{\prime} \mathrm{N}$ & $16^{\circ} 02.4^{\prime} \mathrm{W}$ & $1503 \mathrm{~m}$ (3 specimens) ${ }^{1}$ \\
\hline & & & $29^{\circ} 20.2^{\prime} \mathrm{N}$ & $12^{\circ} 35.1^{\prime} \mathrm{W}$ & $1635 \mathrm{~m}$ (1 specimen $)^{1}$ \\
\hline \multirow[t]{3}{*}{13} & $\begin{array}{l}\text { Stephalia dilata } \\
\text { (Bigelow, 1911) }\end{array}$ & E Pacific & $01^{\circ} 34.4^{\prime} \mathrm{S}$ & $89^{\circ} 30.2^{\prime} \mathrm{W}$ & $\begin{array}{l}\text { 1158m (Type, of } 1 \\
\text { specimen) }\end{array}$ \\
\hline & & NE Pacific & $35^{\circ} 45^{\prime} \mathrm{N}$ & $122^{\circ} 45^{\prime} \mathrm{W}$ & $\begin{array}{l}\text { 1702-2805m (images } \\
\text { only) }\end{array}$ \\
\hline & & $\begin{array}{l}\text { Gulf of } \\
\text { California }\end{array}$ & $24.31^{\circ} \mathrm{N}$ & $109.20^{\circ} \mathrm{W}$ & $1349 \mathrm{~m}(1 \text { specimen })^{8}$ \\
\hline \multirow[t]{4}{*}{14} & $\begin{array}{l}\text { Thermopalia } \\
\text { taraxaca } \text { Pugh, } \\
1983\end{array}$ & E Pacific & $0^{\circ} 48.25^{\prime} \mathrm{N}$ & $86^{\circ} 13.48^{\prime} \mathrm{W}$ & $\begin{array}{l}\text { 2480m (Type, of } 1 \\
\text { specimen) }\end{array}$ \\
\hline & & & $0^{\circ} 47.92^{\prime} \mathrm{N}$ & $86^{\circ} 13.5^{\prime} \mathrm{W}$ & c. $2500 \mathrm{~m}(2$ specimens $)$ \\
\hline & & & $0^{\circ} 47.70^{\prime} \mathrm{N}$ & $86^{\circ} 07.74^{\prime} \mathrm{W}$ & c. $2500 \mathrm{~m}(6 \text { specimens })^{1}$ \\
\hline & & & $35^{\circ} 45^{\prime} \mathrm{N}$ & $122^{\circ} 45^{\prime} \mathrm{W}$ & $\begin{array}{l}2,741-2938 \mathrm{~m} \text { (image } \\
\text { only) }\end{array}$ \\
\hline 15 & $\begin{array}{l}\text { Tridensa rotunda } \\
\text { Hissmann, } 2005\end{array}$ & Indo-Pacific & $01^{\circ} 41.26^{\prime} \mathrm{N}$ & $124^{\circ} 45.95^{\prime} \mathrm{E}$ & $\begin{array}{l}\text { 246m (Type, of } 1 \\
\text { specimen) }{ }^{2}\end{array}$ \\
\hline \multirow[t]{2}{*}{16} & $\begin{array}{l}\text { Tridensa } \\
\text { sulawensis } \\
\text { Hissmann, } 2005\end{array}$ & $\begin{array}{l}\text { NE Sulawesi, } \\
\text { Indonesia }\end{array}$ & $03^{\circ} 39.34^{\prime} \mathrm{N}$ & $126^{\circ} 24.19^{\prime} \mathrm{E}$ & $205 m(1 \text { specimen })^{2}$ \\
\hline & & & $01^{\circ} 24.26^{\prime} \mathrm{N}$ & $124^{\circ} 38.93^{\prime} \mathrm{E}$ & $221 \mathrm{~m}(1 \text { specimen })^{2}$ \\
\hline
\end{tabular}

Sources: 1 Pugh 1983; 2 Hissmann 2005; 3 Hissmann et al 1995; 4 Gutt \& Starmans 1998; 5 Mapstone \& Ljubenkov 2013; 6 Moser 1924; 7 Burton \& Lundsten 2008; 8 Dunn et al 2005; 9 Araujo 2012; 10 Kawamura 1954; 11 Miyake \& Lindsay 2013; 12 Kitamura et al 2008. Type material of Angelopsis globosa, Steleophysema aurophora, Stephalia bathyphysa, S.corona and S. dilata all now lost (see relevant references above). 
Table II. Important rhodaliid characters used to interpret images in Figure 2

\begin{tabular}{|c|c|c|c|c|c|c|c|c|}
\hline Genera: & $\begin{array}{l}\text { Angelops } \\
\text { is }\end{array}$ & $\begin{array}{l}\text { Aranciali } \\
a\end{array}$ & $\begin{array}{l}\text { Archang } \\
\text { elopsis }\end{array}$ & $\begin{array}{l}\text { Dromali } \\
a\end{array}$ & Rhodalia & Stephalia & $\begin{array}{l}\text { Steleoph } \\
\text { ysemal } \\
\text { Tridensa }\end{array}$ & $\begin{array}{l}\text { Thermop } \\
\text { alia }\end{array}$ \\
\hline Live images & none & colour & colour & colour & colour & colour & colour & colour \\
\hline \multicolumn{9}{|l|}{ Characters: } \\
\hline $\begin{array}{l}\text { Pneumatophor } \\
\text { e }\end{array}$ & smooth & smooth & smooth & turreted & smooth & $\begin{array}{l}\text { typically } \\
\text { smooth }\end{array}$ & smooth & smooth \\
\hline Aurophore & smooth & smooth & papillate & papillate & smooth & smooth & smooth & smooth \\
\hline Nectophores & $8-16+$ & $5-20$ & $10-24$ & $12-78$ & $27-80$ & $17-30$ & $8-18+$ & $11-17$ \\
\hline Corm & $\begin{array}{l}\text { thick } \\
\text { walled, } \\
\text { hollow }\end{array}$ & $\begin{array}{l}\text { thin } \\
\text { walled, } \\
\text { hollow }\end{array}$ & $\begin{array}{l}\text { thin } \\
\text { walled, } \\
\text { hollow } \\
(\text { A. } \\
\text { jagoa })\end{array}$ & solid & solid & solid & $\begin{array}{l}\text { thick } \\
\text { walled, } \\
\text { hollow }\end{array}$ & $\begin{array}{l}\text { thin } \\
\text { walled, } \\
\text { hollow }\end{array}$ \\
\hline $\begin{array}{l}\text { Siphosomal } \\
\text { whorls }\end{array}$ & $2-3$ & unknown & 1 & $<15$ & 2 & $\begin{array}{l}2(S . \\
\text { corona })\end{array}$ & unknown & $4-7$ \\
\hline $\begin{array}{l}\text { Type of } \\
\text { cormidium }\end{array}$ & $\begin{array}{l}\text { perhaps } \\
\text { polygastr } \\
\text { ic }\end{array}$ & $\begin{array}{l}\text { monogas } \\
\text { tric }\end{array}$ & $\begin{array}{l}\text { monogas } \\
\text { tric }\end{array}$ & $\begin{array}{l}\text { polygastr } \\
\text { ic }\end{array}$ & polygastric & polygastric & $\begin{array}{l}\text { polygastr } \\
\text { ic }\end{array}$ & $\begin{array}{l}\text { polygastr } \\
\text { ic }\end{array}$ \\
\hline $\begin{array}{l}\text { Type I } \\
\text { gastrozooids }\end{array}$ & $\begin{array}{l}\text { from } \\
\text { base } \\
\text { when } \\
\text { mature }\end{array}$ & $\begin{array}{l}\text { from } \\
\text { base } \\
\text { when } \\
\text { mature }\end{array}$ & $\begin{array}{l}\text { from } \\
\text { base } \\
\text { when } \\
\text { mature }\end{array}$ & $\begin{array}{l}\text { on } \\
\text { cormidial } \\
\text { units in } \\
\text { whorls, } \\
\text { not from } \\
\text { base }\end{array}$ & $\begin{array}{l}\text { probably } \\
\text { from base } \\
\text { when } \\
\text { mature }\end{array}$ & $\begin{array}{l}\text { probably } \\
\text { from base } \\
\text { when } \\
\text { mature }\end{array}$ & $\begin{array}{l}\text { arising } \\
\text { from } \\
\text { corm } \\
\text { itself, } \\
\text { between } \\
\text { cormidial } \\
\text { units or } \\
\text { at base }\end{array}$ & $\begin{array}{l}\text { probably } \\
\text { on } \\
\text { cormidial } \\
\text { units in } \\
\text { whorls, } \\
\text { not from } \\
\text { base }\end{array}$ \\
\hline $\begin{array}{l}\text { Type II } \\
\text { gastrozooids }\end{array}$ & $\begin{array}{l}\text { probably } \\
\text { one per } \\
\text { cormidiu } \\
\text { m } A \text {. } \\
\text { globosa) }\end{array}$ & $\begin{array}{l}\text { one per } \\
\text { cormidiu } \\
\mathrm{m}\end{array}$ & $\begin{array}{l}\text { one per } \\
\text { cormidiu } \\
\mathrm{m}\end{array}$ & $\begin{array}{l}<4 \text { on } \\
\text { one } \\
\text { cormidial } \\
\text { unit }\end{array}$ & $\begin{array}{l}2+\text { per } \\
\text { cormidial } \\
\text { unit }\end{array}$ & $\begin{array}{l}3 \text { on one } \\
\text { cormidial } \\
\text { unit }\end{array}$ & $\begin{array}{l}\text { several } \\
\text { per } \\
\text { cormidial } \\
\text { unit }\end{array}$ & $\begin{array}{l}\text { probably } \\
<4 \text { on } \\
\text { one } \\
\text { cormidial } \\
\text { unit }\end{array}$ \\
\hline Gonopalpons & $\begin{array}{l}\text { clusters } \\
\text { on } \\
\text { gonoden } \\
\text { dra }\end{array}$ & $\begin{array}{l}\text { clusters } \\
\text { on } \\
\text { gonoden } \\
\text { dra }\end{array}$ & $\begin{array}{l}\text { clusters } \\
\text { on } \\
\text { gonoden } \\
\text { dra }\end{array}$ & $\begin{array}{l}\text { 17+ per } \\
\text { cormidial } \\
\text { unit }\end{array}$ & $\begin{array}{l}\text { probably } \\
\text { many per } \\
\text { cormidial } \\
\text { unit }\end{array}$ & $\begin{array}{l}\text { many per } \\
\text { cormidial } \\
\text { unit }\end{array}$ & $\begin{array}{l}\text { many per } \\
\text { cormidial } \\
\text { unit }\end{array}$ & absent \\
\hline $\begin{array}{l}\text { Known } \\
\text { species }\end{array}$ & $\begin{array}{l}\text { A.globos } \\
a \\
\text { A.euryale }\end{array}$ & $\begin{array}{l}\text { A. } \\
\text { captonia }\end{array}$ & $\begin{array}{l}\text { A.typica } \\
\text { A.jagoa }\end{array}$ & $\begin{array}{l}\text { D. } \\
\text { alexandri }\end{array}$ & R. miranda & $\begin{array}{l}\text { S. corona } \\
\text { S.dilata }\end{array}$ & $\begin{array}{l}\text { S. } \\
\text { aurophor } \\
\text { a } \\
\text { T.sulawe } \\
\text { nsis } \\
\text { T.rotund } \\
\text { a }\end{array}$ & $\begin{array}{l}T . \\
\text { taraxaca }\end{array}$ \\
\hline Reference(s) & $\begin{array}{l}\text { Fewkes } \\
\text { 1889; } \\
\text { Pugh } \\
1983\end{array}$ & $\begin{array}{l}\text { Hissman } \\
\text { n } 2005\end{array}$ & $\begin{array}{l}\text { Pugh } \\
1983 \text {; } \\
\text { Hissman } \\
\text { n et al } \\
\text { 1995; } \\
\text { Hissman } \\
\text { n } 2005\end{array}$ & $\begin{array}{l}\text { Pugh } \\
1983 ; \\
\text { Mapston } \\
\text { e \& } \\
\text { Ljubenko } \\
\text { v } 2013\end{array}$ & $\begin{array}{l}\text { Pugh 1983; } \\
\text { Araujo } \\
\text { 2012; }\end{array}$ & $\begin{array}{l}\text { Pugh 1983; } \\
\text { Dunn et al } \\
2005 ; \\
\text { Burton \& } \\
\text { Lundsten } \\
2008\end{array}$ & $\begin{array}{l}\text { Pugh } \\
1983 \text {, } \\
\text { Kitamura } \\
\text { et al } \\
2008 \text { (as } \\
\text { Sagamali } \\
\text { a } \\
\text { hinomar } \\
\text { u); } \\
\text { Hissman } \\
\text { n } 2005\end{array}$ & $\begin{array}{l}\text { Ballard } \\
\& \\
\text { Grasslé } \\
1979 ; \\
\text { Pugh } \\
1983 \text {; } \\
\text { Burton \& } \\
\text { Lundsten } \\
2008\end{array}$ \\
\hline
\end{tabular}


Figure 1. World map showing records for all published species worldwide (NB: only total geographical extent of Dromalia alexandri records indicated).

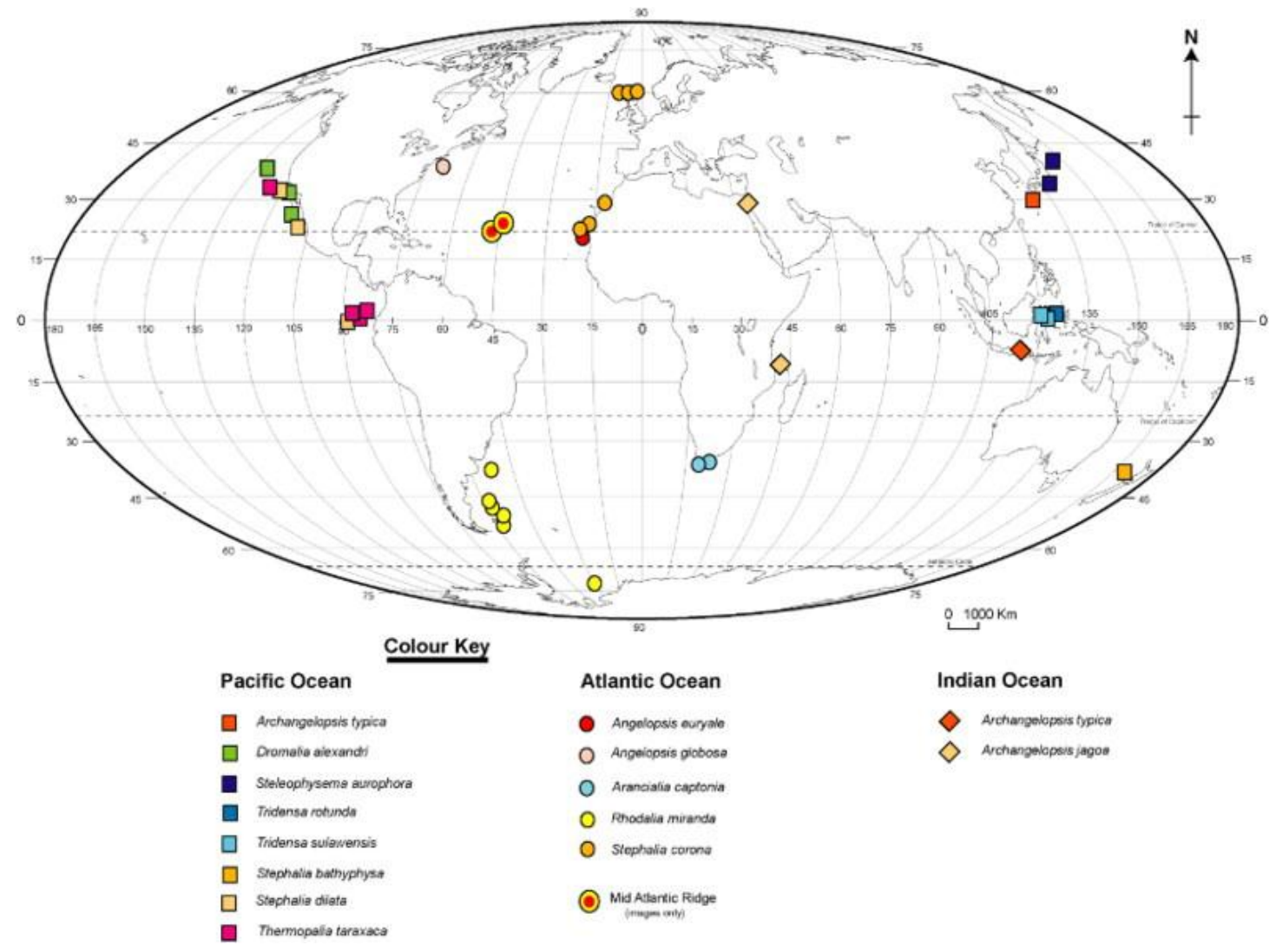


Figure 2. Mid-Atlantic morpho-species morphology. A-B: Species A - orange rhodaliid from Snake Pit vent (lat $23^{\circ} 22.08^{\prime} \mathrm{N}$, long $44^{\circ} 57.2^{\prime} \mathrm{W}$ ), current direction from lower left to top right; C-D: Species B - white rhodaliid from TAG vent (lat $26^{\circ} 08.24^{\prime} \mathrm{N}$, long $44^{\circ} 49.45^{\prime} \mathrm{W}$ ); images $\mathrm{A}$ and $\mathrm{C}$ from live specimens, $\mathrm{B}$ and $\mathrm{D}$ are tentative interpretations of morphology visible from still images. Abbreviations: a aurophore; $\mathrm{b}$ - bract; $\mathrm{n}$ - nectophores; $\mathrm{pn}$ - pneumatophore; $\mathrm{s}$ - substrate; $\mathrm{t}$ - tentacle; $\mathrm{t}^{\mathrm{I}} \mathrm{gZ}$ - type I gastrozooid; $\mathrm{t}^{\mathrm{II}} \mathrm{gZ}$ - type II gastrozooid. Images $\mathbf{A}, \mathbf{C}$ enhanced with Photoshop (highlights, shadow, contrast).
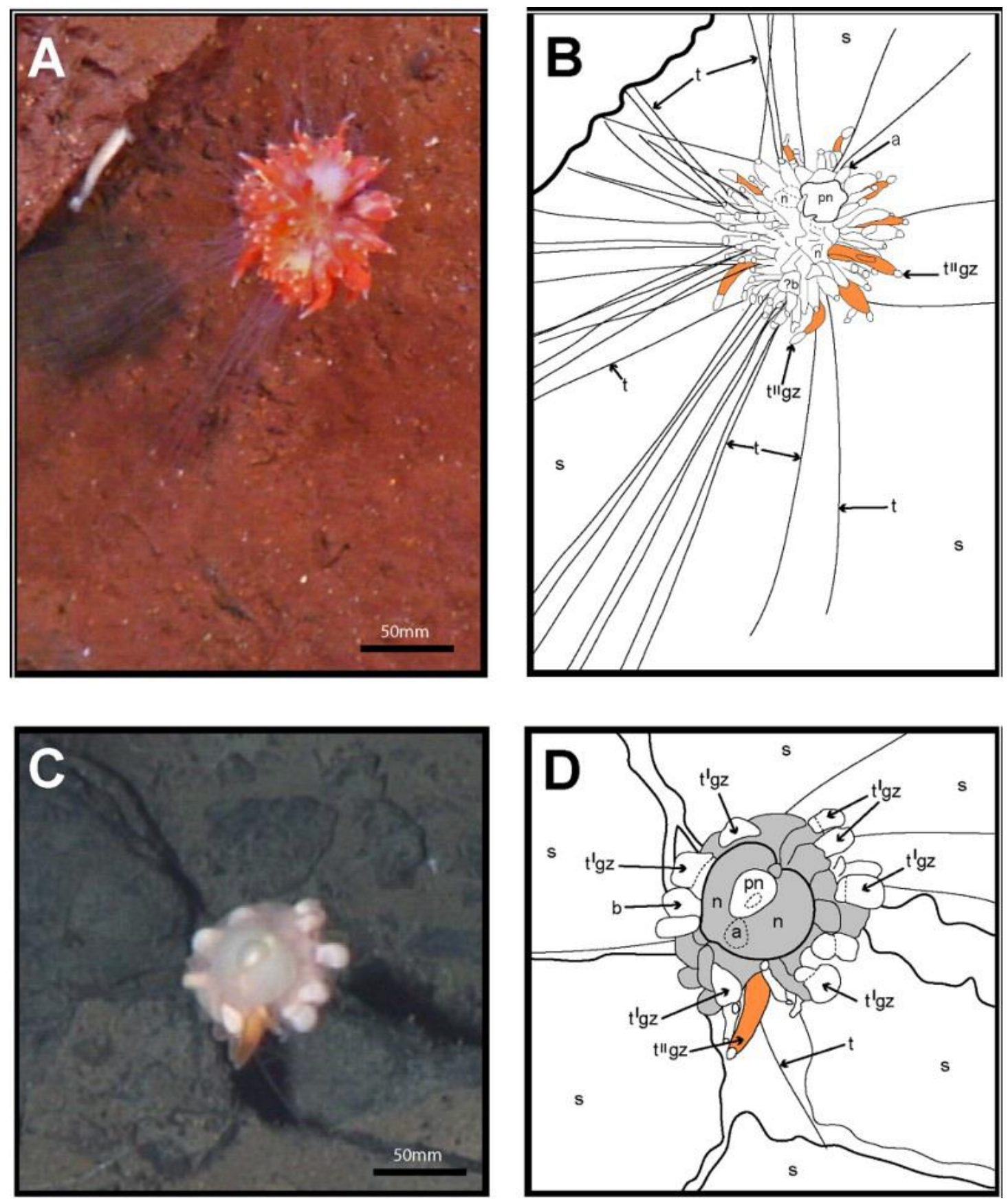


\section{Supplemental Material.}

MAR rhodaliid videos from ROV Victor 6000 taken during the Bicose cruise (2014)

Mapstone et al. submitted.mp4 